\title{
O Imperial Instituto Fluminense de Agricultura: ciência, Estado e proprietários rurais
}

\author{
The Imperial Fluminense Institute of Agriculture: science, \\ State and landowners
}

\author{
Francivaldo Alves Nunes \\ Professor, Programa de Pós-graduação em História Social da Amazônia (Campus de Belém); \\ Programa de Pós-graduação em Educação e Cultura (Campus de Cametá)/Universidade Federal do Pará. \\ fan@ufpa.br
}

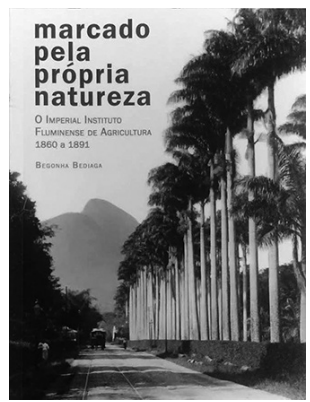

BEDIAGA, Begonha. Marcado pela própria natureza: o Imperial Instituto Fluminense de Agricultura, 1860 a 1891. Rio de Janeiro: Editora FGV. 2014. 236p.
$M$ arcado pela própria natureza é uma contribuição significativa para história do Imperial Instituto Fluminense de Agricultura (Iifa). Não se trata de um exercício descritivo da trajetória do instituto nem revelações de eventos e ações que a instituição promoveu ao longo de sua trajetória. Constitui uma análise dos diversos projetos de melhoramentos da agricultura, de incorporação de práticas científicas e de introdução de máquinas e instrumentos agrícola, em um contexto em que a ciência agronômica no Brasil se conformava tipicamente como aplicada.

O texto de Begonha Bediaga, publicado em 2014, é resultado de pesquisa para sua tese de doutoramento defendida em 2011 no Programa de Pós-graduação em Ensino e História da Ciência da Terra, da Universidade Estadual de Campinas. Defende a criação do Iifa e do seu principal veículo de publicação, a Revista Agrícola, como resultado de uma ação do Estado imperial em busca do apoio de produtores rurais e com o propósito de incrementar a agricultura no país. Em resposta a uma historiografia de pouca referência ao Iifa e que não o reconhecia como instituição científica do século XIX ou associação científica, Bediaga apresenta uma forma de análise em que a preocupação não é compreender o instituto como agremiação de representação dos grandes proprietários rurais da província do Rio de Janeiro, mas o papel que desempenhou na produção de conhecimento científico e sua influência no estabelecimento, no Brasil, de instituições públicas no campo das ciências agrárias.

Para compreender o Iifa como projeto prospectivo e educacional a autora apresenta, em um primeiro momento, a conjuntura em que foram criados os demais institutos agrícolas na Bahia, Pernambuco e Sergipe. A preocupação é mostrar que os debates que envolveram a criação dessas instituições ocupavam um espaço importante na agenda pública do governo 
imperial e envolviam as principais questões políticas e econômicas da década de 1850, em especial as que estavam vinculadas à produção agrícola.

A abordagem do Iifa quanto a seus objetivos, práticas, estrutura administrativa e executiva, composição social, às principais personagens e às fases por que passou nos 31 anos de existência se faz nas questões trabalhadas no segundo capítulo da obra. Destaca a atuação de Luís Pedreira do Couto Ferraz, o visconde do Bom Retiro, que dirigiu o instituto de forma centralizada e personalista. Ainda nesse capítulo, apresenta um panorama do Congresso Agrícola de 1878, organizado pelo governo imperial para debater a lavoura no país. Apesar de o Iifa não ter participado oficialmente do evento, proporcionou elementos de análise sobre os proprietários rurais, permitindo revelar suas relações com as ciências agronômicas e as intenções quanto às atividades vinculadas ao melhoramento no cultivo de plantas, uso de sementes e instrumentos de plantio e colheita.

No terceiro capítulo a autora analisa o principal veículo de comunicação do instituto com a sociedade, a Revista Agrícola, criada em 1869. Nessa etapa, o escopo do periódico, seus redatores e editoriais são objetos de atenção, com o propósito de analisar a rede de relacionamentos e os campos disciplinares que na época emergiam no país. A Revista Agrícola aparece como um canal de comunicação científica voltado ao público que se ocupava de atividades rurais, ou, nos termos de época, um espaço de "vulgarização científica". Observa-se a preocupação em mostrar que o interesse maior do periódico era contribuir para que o Brasil seguisse rumo ao aumento da produção e melhoria da qualidade da agricultura.

No último capítulo, aborda o episódio de combate à moléstia da cana-de-açúcar ocorrido entre 1867 e 1870, que mobilizou proprietários rurais, homens das ciências e o governo. A proposta é entender o significado da moléstia no contexto das mudanças técnicas e científicas que ocasionaram transformações na prática agrícola na Europa e nos Estados Unidos, principalmente a partir de 1840, com enfoque na química e em outras teorias que afetaram profundamente a agricultura. Esse episódio, ao qual o instituto dedicou-se, é apresentado em uma conjuntura em que o apoio do governo pode ser compreendido no contexto de uma política imperial empenhada em administrar as consequências da decadência da lavoura canavieira. A moléstia aparece nos registros de Bediaga como produtor de um abalo na trajetória societária do Iifa, uma vez que posterior à atuação do instituto no combate a doença, coincidentemente ou não, a autora observa um decrescente número de reuniões, sendo que, a partir de 1876, não se encontram mais indícios da realização dessa atividade. São observadas pela autora as divergências a respeito da moléstia da cana-de-açúcar, que evidenciavam as diferentes posições de proprietários rurais, Estado e homens da ciência, e que, embora tenham provocado discordâncias por parte dos sócios do instituto, criaram um ambiente propício à boa receptividade das ciências e da tecnologia na agricultura brasileira.

Marcado pela própria natureza se configura, portanto, como contribuição à história não só das elites agrárias do país, mas também das elites técnico-científicas do Segundo Reinado. A obra de Begonha Berdiaga é uma contribuição à história da agricultura, à história da química, mas também à história da institucionalização da agronomia no país, via o Iifa. E como não se poderia deixar de registrar, traz elementos para pensar a história da escravidão. No caso, o texto apresenta uma preocupação construída entre intelectuais, políticos e cientistas em superar a escassez de braços para a lavoura, por meio do desenvolvimento da ciência e da 
técnica agrícola, o que imporia um maior volume de produção, sem a necessidade de aquisição de novos trabalhadores escravos.

O constante trânsito por terrenos históricos e metodológicos diversos como história da intelectualidade, ciência, técnica e tecnologia é outra qualidade observada no texto. Há momentos em que a questão central é o universo mental. Isso se constata quando a autora analisa o pensamento de intelectuais, políticos e cientistas que atuaram no Iifa. Bediaga percebe o que estava no bojo de escritos políticos de um homem de Estado como Couto Ferraz. Por outro lado, há momentos em que o envolvimento social e as experiências que buscavam promover a modernização da agricultura no Brasil sobressaem. Assim, a análise apresenta, de forma indissociável, a história do lifa como um universo mental, de pensamentos e ideias, e a materialização de projetos e proposições. 


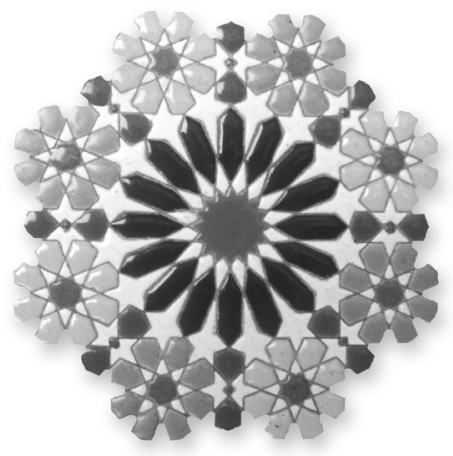

